\begin{abstract}
Методом експертних оцінок обгрунтовано, що найбільш вагомими факторами, які суттєво впливають на механізм та кінетику технологічних процесів приготування регенерованоі суміші, є температура приготування суміші та вміст регенеруючої добавки. Досліджено їх вплив на фізико-механічні показники регенерованого асфальтобетону, отриманого за технологією гарячого ресайклінгу асфальтобетонного покриття методом «іn place». При проведенні експериментальних досліджень отримані залежності фізико-механічних показників (водонасичення, мічність на стиск при $0^{\circ} \mathrm{C}$ та при $50^{\circ} \mathrm{C}$ ) регенерованого асфальтобетону від вмісту добавки та температури перемішування. Отримано математичні моделі у вигляді поліномів другого ступеню, що описують залежність водонасичення та міцності при стиску регенерованого асфальтобетону від температури приготування та вмісту регенеруючої добавки. Встановлено що із збільшенням температури перемішування збільшується міцність на стиск при $0^{\circ} \mathrm{C}$, в той же час міцність на стиск при $50^{\circ} \mathrm{C}$ та показник водонасичення зменшуються. Із збільшенням регенеруючої добавки всі фізико-механічні показники, які були досліджені, зменшуються. На основі аналізу отриманих результатів встановлені області рачіональних значень температури перемішування розпушеної асфальтобетонної крихти $(125-135)^{\circ} \mathrm{C}$, та вмісту добавки $(0,26-0,28) \%$ при приготуванні регенерованої гарячої асфальтобетонної суміші. Отримана суміш за фізико-технічними показниками задовольняє вимоги ДСТУ Б В.2.7-119:2011 «Сумімі асфальтобетонні $i$ асфальтобетон дорожній та аеродромний. Технічні умови» до гарячих дрібнозернистих асфальтобетонних сумішей. Отримані результати корисні при проектуванні технології гарячого ресайклінгу асфальтобетонного покриття методом «іп place» та в дослідженнях, пов'язаних з ї удосконалюванням

Ключові слова: гарячий ресайклінг, асфальтобетон, експериментально-статистичне моделювання, температура перемішування, регенеруюча добавка
\end{abstract}

UDC 625.85

DOI: $10.15587 / 1729-4061.2020 .203947$

\section{SUBSTANTIATING THE CHOICE AND OPTIMIZING THE PARAMETERS FOR THE TECHNOLOGY OF HOT RECYCLING OF ASPHALT CONCRETE ROAD COATING}

V. S a ve nko

Doctor of Technical Sciences, Professor, Head of Department*

E-mail: svi1310@ukr.net

V. Honcharenko $\mathrm{PhD}$, Associate Professor* E-mail: gonchvv11@gmail.com

S. Illias h

Head of Department** E-mail: sergillyash@gmail.com

A. Mudrychenko

Head of Laboratory Laboratory of Road Construction*** E-mail: mudrychenko@gmail.com

I. B a I a shov Researcher**

E-mail: balashov_io@ukr.net *Department of Transport Construction and Property Management

National Transport University Mykhaila Omelianovycha-Pavlenka, str., 1, Kyiv, Ukraine, 01010

**Department of Normative and Engineering of Roadworks*** ***M. P. Shulgin State Road Research Institute State Enterprise - Derzhdor NDI SE Peremohy ave., 57, Kyiv, Ukraine, 03113

\section{Introduction}

The growth of vehicle capacity and traffic intensity requires continuous development of road network, improvement of road paving structures. At the same time, it is necessary to pay special attention to the current repair of highways, that is, systematic and timely recovery of operational status, the correction of minor damage to road paving. That would make it possible to minimize the cost of operations on
Copyright $\odot$ 2020, V. Savenko, V. Honcharenko, S. Illiash, A. Mudrychenko, I. Balashov This is an open access article under the CC BY license (http://creativecommons.org/licenses/by/4.0) 
- continuous milling of the upper layer of the existing road surface with its subsequent replacement;

- the construction of wear layers made from cast emulsion-mineral mixtures and surface finishes.

They all imply replacing the upper layer of the road surface or constructing the new wear layers. This causes a series of significant drawbacks [1]:

- significant financial cost for arranging new coating layers;

- the need to dispose of the old material coating;

- raising high rise marks of the coating (especially streets and driveways in cities and other settlements, bridge crossings);

- existing probability of reflected damage occurrence over time;

- increasing the load on bridge structures from their mass while constructing the coating layers.

Under such conditions, the priority fields of research are resource-saving technologies, whose application makes it possible to achieve a significant financial economy by optimizing construction processes, using modern construction equipment, and reusing building materials [1-3]. These technologies include the hot recycling of asphalt concrete using the «in place» method.

A significant advantage of asphalt concrete recycling technology using the «in place» method is that the full cycle of operations is performed by specialized equipment over a single working run.

The advantages of this technology also include a one hundred percent use of the material of the existing asphalt pavement, a tight timeframe for operation execution, the possibility to perform work while blocking traffic along a single lane only [2].

The main condition for the efficient application of the technology is the structural integrity of road paving layers arranged below in the case where a top layer of coating has a lot of defects in the form of cracks or grids of cracks, tracks, irregularities, as well as landslides, associated with the insufficient shear resistance of asphalt concrete. At this kind of repair, old material is completely utilized [2].

At the same time, the effectiveness of a given technology significantly depends on the quality of the resulting regenerated mixture. Currently, there is a need to study dependences of the physical and mechanical indicators of the regenerated hot asphalt concrete mixture on the simultaneous influence of several significant factors in the process of its making. Therefore, such research is relevant. Establishing the dependence of factors that influence the process of asphalt concrete hot recycling would make it possible to optimize the technology and reduce the cost of operations.

\section{Literature review and problem statement}

It was established in work [4] that the hot regeneration of road paving is most effective when the service life does not exceed (8-10) years at an inter-repair period of $(12-14)$ years. Over this period, road paving loses only about $40 \%$ of quality; at the same time, over the next (2-4) years the residual resource decreases to $20 \%$. Timely repairs would make it possible to prevent the rapid development of damage to the road surface and prolong its service life. The cited paper studied the effect of the content of old bitumen on the qualitative characteristics of regenerated asphalt concrete. At the same time, these data are general and do not reflect the dependence of the durability of the repaired coating on the integrated influence of internal structural and external weather and climatic factors.

The authors of work [5] showed that it is very important, at the hot regeneration of asphalt concrete, to consider the change in the properties of bitumen, which is the main component that characterizes the performance of regenerated asphalt concrete. The reason for a change in the bitumen properties is its operational aging, which occurs under the influence of different weather and climatic factors (temperature, oxygen, and ultraviolet radiation).

In addition, the research results reported in works [2, 6] indicate that the additional intensive aging of bitumen occurs during the asphalt concrete hot recycling process when using the «in place» method due to the harsh conditions of warming up the coating by an asphalt preheater. This is manifested in the significant decrease in the rate of bitumen penetration, by (20-25) \%, and in the loss of a set of operational characteristics by asphalt concrete. However, the cited works did not consider issues related to the change in the physical and mechanical properties of regenerated asphalt concrete depending on stirring temperature. The influence of high technological temperatures leads to the evaporation of low-molecular components of the organic binder in oils and, partly, resins. This makes the binder more solid, brittle, and less deformable. The asphalt concrete mix containing such a binder would not be durable while the technology of hot recycling would prove economically inadequate. All this allows us to argue about the need to establish optimal technological temperatures and to search for ways to reduce the technological aging of bitumen.

One solution to the problem of bitumen aging can be the use of regenerating additives - products based on heavy petroleum oils, or other composition. The introduction of such additives ensures the plasticization of residual bitumen and partial restoration of its operational properties [7, 8]. In order to resolve the issue of bitumen aging when compiling the formulations for regenerated asphalt concrete, paper [4] noted the importance of adding new bitumen.

In practice, it was determined that the content of residual bitumen in the milled asphalt concrete can vary from 4 to $8 \%$. However, at present, despite the presence of a large number of different types of regenerating additives in the market, there are no data on the exact number of their dosage depending on the content of residual bitumen for various types of asphalt concrete mixtures.

Given the high market price of regenerating additives, it is advisable to determine their optimum amount depending on the content of residual bitumen at which a set of the operational properties of regenerated asphalt concrete would be optimal.

An important component of the technological process of asphalt concrete hot recycling using the «in place» method is warming an asphalt concrete coating to a certain depth utilizing the thermal energy of infrared irradiation [9].

The results of testing asphalt concrete samples after repeated warming, reported in papers $[9,10]$, indicate that asphalt concrete does not change its characteristics at the temperatures not exceeding $180^{\circ} \mathrm{C}$ and at the duration of warming to 30 minutes. When maintaining the temperature at the surface of an asphalt concrete coating of $(160-180){ }^{\circ} \mathrm{C}$, the depth of warming the asphalt concrete, before its transition to a plastic state, reaches $(4-6) \mathrm{cm}$ at the specific dimensions and motion speed of an asphalt preheater [9]. Approximate values of asphalt-concrete tempera- 
ture at a different distance from the surface are given in [9]. However, the cited work does not account for the influence of the speed of an asphalt preheater on the depth of warming an asphalt concrete layer. At the same time, work [9] established a minimum temperature of the preliminary heating of a road surface, $120^{\circ} \mathrm{C}$, which ensures the effective stirring of an asphalt concrete mixture and qualitative indexes of the regenerated coating.

The authors of papers $[8,10]$ determined the influence of the temperature and duration of stirring the mixture on its homogeneity. This research showed that increasing the uniformity of the mixture is achieved by increasing the heating temperature. One way to improve the uniformity of the mixture can also be an increase in the duration of its stirring.

However, studying the boundary values of the warming temperature of the road surface and the preparation of regenerated hot asphalt concrete mixtures does not give full information about optimal temperature regimes as the heating range is quite wide $-(120-180)^{\circ} \mathrm{C}$.

Paper [11] showed that the insufficient warming temperature of a coating is one of the main causes of poor-quality work on the hot recycling of asphalt concrete using the «in place» method. On the other hand, the excessively high temperature of coating warming accelerates the aging of bitumen and reduces the quality of the regenerated mixture.

The warming and stirring temperature of the regenerated asphalt concrete mix is an important factor defining the quality of the regenerated asphalt concrete layer of coating. Determining its rational value is a relevant scientific task, which has both theoretical and practical significance.

Thus, based on an analysis of the practical experience of using the technology of hot recycling of asphalt concrete on roads, one should note that a series of scientific works addressed the influence of factors on the kinetics of technological processes for preparing the regenerated mixture. These factors include the temperature of coating warming, the content of old and added bitumen, the content of a regenerating additive, the mixture stirring temperature at preparation, the stirring time, as well as its uniformity. However, still to be addressed are issues to justify the weight of factors that significantly affect the physical and mechanical characteristics of regenerated asphalt concrete and to determine the optimal technological regimes of its preparation. The solutions reported in works $[3,7,8,10,12]$ are mostly based on establishing the influence of individual factors on the physical-mechanical properties of the regenerated asphalt concrete. This allows us to argue about the expediency of research into the influence of several weighty factors at the same time, which corresponds to the actual situation when applying hot recycling.

\section{The aim and objectives of the study}

The aim of this study is to optimize the temperature mode of mixture preparation, as well as the content of a regenerating additive at the hot recycling of asphalt concrete coating using the «in place» method. In this case, the regenerated mixture must meet, in terms of the indicators of physical and mechanical properties, the requirements set by regenerated mixture «Asphalt-concrete mixtures and road and airfield asphalt concrete. Technical specifications» for the hot finegrained asphalt concrete mixtures. This would enable the strength and durability of the road surface.
To accomplish the aim, the following tasks have been set:

- to establish the most significant factors that considerably affect the physical and mechanical indicators of regenerated asphalt concrete;

- to conduct an experimental study into the influence of the substantiated weighty factors on the physical-mechanical parameters of regenerated asphalt concrete;

- to determine the regions of rational values for the substantiated factors.

\section{Research methods and materials to study the process} of preparing regenerated hot asphalt concrete mixture

The material chosen for the study was a regenerated hot asphalt concrete mixture, whose grain composition and bitumen content matched the hot, fine-grained, dense asphalt concrete, type A, unintermittent granulometry, grade II, in accordance with DSTU B V.2.7-119:2011. The content of the residual bitumen in loose asphalt-concrete crumbs was $6.0 \%$.

The regenerating additive used was a «rejuvenating» additive, silane-based, in combination with vegetable and paraffin oils whose application makes it possible to ensure the plasticization of old bitumen.

The study was carried out at the laboratory of the State Enterprise «State Road Research Institute named after M. P. Shulgin» (DP «DerzhdorNDI») using the following equipment: temperature chamber, the type of «MATEST»; the hydraulic press «MATEST»; the vacuum plant «UV-12»; a laboratory scales of accuracy class 4 according to DSTU EN 45501.

The research methods were determined in accordance with DSTU B V.2.7-319:2016 «Asphalt concrete mixes and road and airfield asphalt concrete. Test methods».

For testing, we made samples from the regenerated asphalt concrete mixture at different preparation temperatures and with different amounts of additives. The preparation temperature was determined and maintained by the temperature chamber, the type of «MATEST».

The tests were carried out based on the indicators of water saturation and the boundary of compressive strength at temperature $0{ }^{\circ} \mathrm{C}$ and $50{ }^{\circ} \mathrm{C}$.

Determining water saturation implies measuring the amount of water absorbed by a sample under the predefined saturation mode. Water saturation is determined on the samples made from the mixture in the laboratory. The result of determining water saturation is the mean arithmetic value of three measurements rounded to the first decimal symbol.

Compressive strength is determined by finding the boundary stress, which leads to the destruction of a sample under the predefined test conditions. Determining tensile strength at compression is performed on samples, manufactured in accordance with the requirements of normative documents. At each predefined temperature, we tested three samples. The tested samples are of the same age.

In order to establish the most important factors influencing the physical-mechanical indicators of regenerated asphalt concrete, the method of expert assessments [13-15] was used.

The general procedure of expert polls included the following stages:

- selection of experts;

- formation of questions and preparation of questionnaires; work with experts; 
- formation of rules for determining the summary estimates based on assessments by individual experts;

- analysis and processing of expert assessments.

The method of experimental and statistical modeling was applied to optimize the parameters of hot recycling technology.

A multivariate experiment was conducted to construct a mathematical model and assess the values of optimization parameters. For the end result of each series of experiments, the arithmetic mean of the three test results for each response function value was accepted.

During our study, we determined the confidence interval for each experiment and compared it with the total spread of values.

The result was the derived regression equation coefficients, based on which we constructed mathematical models that characterize the response functions. The established dependences were simulated in the STATISTICA programming environment.

\section{Results of studying the optimization of asphalt concrete coating hot recycling technology parameters}

\section{1. Determining factor weights}

The factors included in the survey were the basic technological and technical indicators (Table 1). The choice of factors was substantiated by the expert assessment of specialists and requirements set by DSTU B V.2.7-119:2011 «Asphalt concrete mixes and road and airfield asphalt-concrete. Technical specifications».

Table 1

\section{Factors and their encoded designations}

\begin{tabular}{|l|c|}
\hline \multicolumn{1}{|c|}{ Examined variable (factor) } & Factor designation \\
\hline Old bitumen content & $X_{1}$ \\
\hline Added bitumen content & $X_{2}$ \\
\hline Mixture stirring temperature at preparation & $X_{3}$ \\
\hline Regenerating additive content & $X_{4}$ \\
\hline Mixture stirring duration at preparation & $X_{5}$ \\
\hline Coating warming temperature & $X_{6}$ \\
\hline Granular composition & $X_{7}$ \\
\hline Mixture compression temperature & $X_{8}$ \\
\hline Stirring homogeneity & $X_{9}$ \\
\hline
\end{tabular}

10 experts took part in the survey. In order to obtain the most objective results, the chosen experts were qualified specialists from the following representatives:

- contractors - TOV «STI» (Ukraine), TOV «ABZ-1» (Ukraine);

- clients - Road service in Chernihiv and Chernivtsi oblasts (Ukraine);

- scientific research institutions - National Transport University (Ukraine), Odesa National Academy of Construction and Architecture (Ukraine), DP «DerzhdorNDI» Ukraine).

The main criterion of expert selection was the practical experience of using asphalt concrete hot recycling technolo- gies. Based on questionnaire data, we constructed a consolidated matrix of ranks (Table 2).

$a_{i}$ is the rank of the $i$-th factor by the $j$-th polled expert, $n$ is the number of experts polled.

Table 2

\section{Consolidated matrix of ranks}

\begin{tabular}{|c|c|c|c|c|c|c|c|c|c|}
\hline \multirow{2}{*}{$\begin{array}{l}\text { A specialist who } \\
\text { participates in the } \\
\text { survey }\end{array}$} & \multicolumn{9}{|c|}{ Ranks of factors included in the survey } \\
\hline & $X_{1}$ & $X_{2}$ & $X_{3}$ & $X_{4}$ & $X_{5}$ & $X_{6}$ & $X_{7}$ & $X_{8}$ & $X_{9}$ \\
\hline 1 & 4 & 3 & 2 & 1 & 5 & 6 & 8 & 7 & 9 \\
\hline 2 & 2 & 3 & 1 & 4 & 7 & 4 & 7 & 6 & 5 \\
\hline 3 & 4 & 6 & 2 & 3 & 1 & 5 & 7 & 8 & 9 \\
\hline 4 & 1 & 4 & 3 & 2 & 7 & 4 & 6 & 5 & 7 \\
\hline 5 & 5 & 1 & 2 & 3 & 6 & 4 & 6 & 7 & 5 \\
\hline 6 & 3 & 2 & 4 & 5 & 4 & 1 & 3 & 5 & 6 \\
\hline 7 & 4 & 2 & 3 & 1 & 5 & 6 & 6 & 7 & 7 \\
\hline 8 & 5 & 6 & 3 & 2 & 1 & 5 & 4 & 7 & 5 \\
\hline 9 & 1 & 4 & 2 & 4 & 3 & 5 & 6 & 5 & 7 \\
\hline 10 & 2 & 5 & 3 & 1 & 4 & 7 & 6 & 7 & 5 \\
\hline $\begin{array}{l}\text { The sum of ranks for } \\
\text { factors } \sum_{j=1}^{n} a_{j i}\end{array}$ & 31 & 36 & 25 & 26 & 43 & 47 & 59 & 64 & 65 \\
\hline $\begin{array}{l}\text { The nominal rank of } \\
\text { factors based on the } \\
\text { sum of ranks } a_{i}\end{array}$ & 3 & 4 & 1 & 2 & 5 & 6 & 7 & 8 & 9 \\
\hline
\end{tabular}

Given that some experts could not divide the degree of influence of certain factors and awarded the same ranks, we performed rank conversion.

To this end, each identical rank of the $j$-th specialist is replaced with the converted one, computed from the following ratio [15]:

$$
b=\frac{\sum_{i_{1}}^{k_{1}}\left(k_{2}+i\right)}{k_{1}},
$$

where $k_{1}$ is the number of identical ranks in the corresponding group of ranks for the specified polled expert; $k_{2}$ is the number of factors that are ahead of the group of factors with the identical ranks.

Converted ranks are given in Table 3 .

Checking the correctness of the matrix based on the calculation of the checksum is determined from the following formula [15]:

$$
\sum_{i=1}^{k} b_{j i}=\frac{(1+k) \cdot k}{2},
$$

where $k$ is the number of examined factors.

The next step is the analysis of the significance of the studied factors. Table 3 shows that the most significant factors are $X_{3}$ and $X_{4}$, the least significant $-X_{8}$. 
Table 3

Converted ranks

\begin{tabular}{|c|c|c|c|c|c|c|c|c|c|c|c|c|}
\hline \multirow{2}{*}{$\begin{array}{l}\text { A specialist who } \\
\text { participates in } \\
\text { the survey }\end{array}$} & \multicolumn{9}{|c|}{ Related ranks of factors included in the survey } & \multirow{2}{*}{$\begin{array}{l}\text { Sum of ranks for } \\
\text { experts } \sum_{i=1}^{k} b_{j i}\end{array}$} & \multirow{2}{*}{$\begin{array}{l}\text { The number } \\
\text { of identical } \\
\text { ranks } \eta_{r}\end{array}$} & \multirow{2}{*}{$T_{j}$} \\
\hline & $X_{1}$ & $X_{2}$ & $X_{3}$ & $X_{4}$ & $X_{5}$ & $X_{6}$ & $X_{7}$ & $X_{8}$ & $X_{9}$ & & & \\
\hline 1 & 4.0 & 3.0 & 2.0 & 1.0 & 5.0 & 6.0 & 8.0 & 7.0 & 9.0 & 45 & - & - \\
\hline 2 & 2.0 & 3.0 & 1.0 & 4.5 & 8.5 & 4.5 & 8.5 & 7.0 & 6.0 & 45 & $2 ; 2$ & 12 \\
\hline 3 & 4.0 & 6.0 & 2.0 & 3.0 & 1.0 & 5.0 & 7.0 & 8.0 & 9.0 & 45 & - & - \\
\hline 4 & 1.0 & 4.5 & 3.0 & 2.0 & 8.5 & 4.5 & 7.0 & 6.0 & 8.5 & 45 & $2 ; 2$ & 12 \\
\hline 5 & 5.5 & 1.0 & 2.0 & 3.0 & 7.5 & 4.0 & 7.5 & 9.0 & 5.5 & 45 & $2 ; 2$ & 12 \\
\hline 6 & 3.5 & 2.0 & 5.5 & 7.5 & 5.5 & 1.0 & 3.5 & 7.5 & 9.0 & 45 & $2 ; 2 ; 2$ & 18 \\
\hline 7 & 4.0 & 2.0 & 3.0 & 1.0 & 5.0 & 6.5 & 6.5 & 8.5 & 8.5 & 45 & $2 ; 2$ & 12 \\
\hline 8 & 6.0 & 8.0 & 3.0 & 2.0 & 1.0 & 6.0 & 4.0 & 9.0 & 6.0 & 45 & 3 & 24 \\
\hline 9 & 1.0 & 4.5 & 2.0 & 4.5 & 3.0 & 6.5 & 8.0 & 6.5 & 9.0 & 45 & $2 ; 2$ & 12 \\
\hline 10 & 2.0 & 5.5 & 3.0 & 1.0 & 4.0 & 8.5 & 7.0 & 8.5 & 5.5 & 45 & $2 ; 2$ & 12 \\
\hline $\begin{array}{l}\text { The sum of ranks } \\
\text { by factors } \sum_{i=1}^{n} b_{j i}\end{array}$ & 33.0 & 39.5 & 26.5 & 29.5 & 49.0 & 52.5 & 67.0 & 77.0 & 76.0 & $\sum_{i=1}^{k} \sum_{j=1}^{n} b_{i j}=450$ & - & $\sum_{j=1}^{n} T_{j}=114$ \\
\hline $\begin{array}{l}\text { Conditional rank } \\
\text { by the sum of } \\
\text { ranks } \beta_{i} \\
\end{array}$ & 3 & 4 & 1 & 2 & 5 & 6 & 7 & 9 & 8 & - & - & - \\
\hline $\begin{array}{l}\text { Deviation of the } \\
\text { sum of ranks from } \\
\text { the average } \Delta_{i}\end{array}$ & -17.0 & -10.5 & -23.5 & -20.5 & -1.0 & 2.5 & 17.0 & 27.0 & 26.0 & $\sum_{j=1}^{n} \Delta_{i}=0$ & - & - \\
\hline $\begin{array}{l}\text { Squared } \\
\text { deviations } \Delta_{i}^{2}\end{array}$ & 289.0 & 110.3 & 552.3 & 420.3 & 1.0 & 6.3 & 289.0 & 729.0 & 676.0 & $\sum_{j=1}^{n} \Delta_{i}^{2}=3073$ & - & - \\
\hline
\end{tabular}

To assess the generalized measure of the consistency of opinions on all factors, it is necessary to calculate a concordance coefficient [15]:

$$
W=\frac{12 \cdot \sum_{j=1}^{n} \Delta_{i}^{2}}{\left(n^{2}\left(k^{3}-k\right)-n \cdot \sum_{j=1}^{n} T_{j}\right)},
$$

where

$$
T_{i}=\sum_{\eta_{r}=1}^{l_{j}}\left(\eta_{r}^{3}-\eta_{r}\right)
$$

where $\eta_{r}$ is the group size of identical ranks by the $j$-th specialist; $l_{j}$ is the number of groups of identical ranks by the $j$-th specialist.

The concordance coefficient for a given matrix of values is 0.52 . At full consistency of experts in evaluating the set problem, $W=1$, and in the absence of consistency $W=0$. $W=0.52$ indicates the presence of the medium consistency of the experts' opinions.

In order to assess the importance of the concordance coefficient, we computed Pearson's agreement criterion [15]:

$$
X^{2}=n \cdot(k-1) \cdot W .
$$

The Pearson's agreement criterion, computed for a given matrix, is 41.63 and is larger than the tabular value (15.51) for the number of degrees of freedom $k-1=9-1=8$ at the predefined level of importance $\alpha=0.05$. Given the above, one can conclude that $W=0.52$ is not a random quantity; therefore, the results obtained make sense and can be used in further research.

To calculate the significance of weight of each factor, it is necessary that the matrix, based on the survey results (Table 2), should be represented through the matrix of converted ranks (Table 4) by using the following formula:

$$
S_{i j}=X_{\max }-X_{j},
$$

where $X_{\max }=9$.

Table 4

The matrix of converted ranks

\begin{tabular}{|c|c|c|c|c|c|c|c|c|c|}
\hline \multirow{2}{*}{$\begin{array}{c}\text { A specialist who } \\
\text { participates in } \\
\text { the survey }\end{array}$} & \multicolumn{8}{|c|}{ Ranks of factors included in the survey } \\
\cline { 2 - 12 } & $X_{1}$ & $X_{2}$ & $X_{3}$ & $X_{4}$ & $X_{5}$ & $X_{6}$ & $X_{7}$ & $X_{8}$ & $X_{9}$ \\
\hline 1 & 5 & 6 & 7 & 8 & 4 & 3 & 1 & 2 & 0 \\
\hline 2 & 7 & 6 & 8 & 5 & 2 & 5 & 2 & 3 & 4 \\
\hline 3 & 5 & 3 & 7 & 6 & 8 & 4 & 2 & 1 & 0 \\
\hline 4 & 8 & 5 & 6 & 7 & 2 & 5 & 3 & 4 & 2 \\
\hline 5 & 4 & 8 & 7 & 6 & 3 & 5 & 3 & 2 & 4 \\
\hline 6 & 6 & 7 & 5 & 4 & 5 & 8 & 6 & 4 & 3 \\
\hline 7 & 5 & 7 & 6 & 8 & 4 & 3 & 3 & 2 & 2 \\
\hline 8 & 4 & 3 & 6 & 7 & 8 & 4 & 5 & 2 & 4 \\
\hline 9 & 8 & 5 & 7 & 5 & 6 & 4 & 3 & 4 & 2 \\
\hline 10 & 7 & 4 & 6 & 8 & 5 & 2 & 3 & 2 & 4 \\
\hline Rank sum & 59 & 54 & 65 & 64 & 47 & 43 & 31 & 26 & 25 \\
\hline Total rank sum & \multicolumn{9}{|c|}{$\Sigma=414$} \\
\hline Factor weight & 0.143 & 0.130 & 0.157 & 0.155 & 0.114 & 0.104 & 0.075 & 0.063 & 0.060 \\
\hline
\end{tabular}


Thus, the most significant factors are $X_{3}$ and $X_{4}$, that is, the mixture stirring temperature during preparation and the content of a regenerating additive.

\section{2. Experimental study and mathematical model con-} struction

To conduct the study, it was decided to investigate two of the most significant factors at three levels. Taking into consideration the importance of the impact, we accepted, for determining the optimum compositions of the regenerated hot asphalt concrete mixture, the mixture stirring temperature at preparation and the content of the regenerating additive.

The number of experiments to be conducted can be calculated from the following formula [15]:

$$
N_{e}=3^{n}
$$

where 3 is the number of levels, $n$ is the number of factors. Using formula (7), we determined that the number of experiments required to solve optimization problems is 9 . Based on the a priori information, we selected the intervals of factor variation and encoded them (Table 5).

Table 5

Values of variation factors

\begin{tabular}{|c|c|c|c|c|c|c|}
\hline \multirow{2}{*}{$\begin{array}{c}\text { Fac- } \\
\text { tor } \\
\text { code }\end{array}$} & Factor physical & \multirow{2}{*}{$\begin{array}{c}\text { Mea- } \\
\text { surement } \\
\text { essence }\end{array}$} & $\begin{array}{c}\text { Varia- } \\
\text { tion } \\
\text { interval }\end{array}$ & \multicolumn{3}{|c|}{ Factor value } \\
\cline { 5 - 7 } & & & -1 & 0 & +1 \\
\hline $\mathrm{X}_{1}$ & $\begin{array}{l}\text { Preparation tempe- } \\
\text { rature, T }\end{array}$ & ${ }^{\circ} \mathrm{C}$ & 20 & 100 & 120 & 140 \\
\hline $\mathrm{X}_{2}$ & $\begin{array}{l}\text { Regenerating addi- } \\
\text { tive content, } C_{R A}\end{array}$ & $\%$ & 0.05 & 0.2 & 0.25 & 0.3 \\
\hline
\end{tabular}

The accepted optimization parameters (response functions) were the strength indicators of asphalt concrete, which characterize the behavior of its performance under the most critical conditions - compressive strength at $0{ }^{\circ} \mathrm{C}$ and at $50^{\circ} \mathrm{C}$, as well as the physical indicator - water saturation. The boundary values of the response function were taken for the fine-grained asphalt concrete, type A, unintermittent granulometry, grade II, in accordance with DSTU B V. 2.7-119:2011 (Table 6).

Table 6

Values of optimization parameters (response functions)

\begin{tabular}{|c|l|c|c|}
\hline $\begin{array}{c}\text { Factor } \\
\text { code }\end{array}$ & \multicolumn{1}{|c|}{$\begin{array}{c}\text { Factor physical } \\
\text { essence }\end{array}$} & $\begin{array}{c}\text { Measure- } \\
\text { ment unit }\end{array}$ & $\begin{array}{c}\text { Response function } \\
\text { boundary value }\end{array}$ \\
\hline$Y_{1}$ & $\begin{array}{l}\text { Water saturation, } W, \\
\text { not exceeding }\end{array}$ & $\%$ & 3.5 \\
\hline$Y_{2}$ & $\begin{array}{l}\text { Compressive strength } \\
\text { at } 0{ }^{\circ} \mathrm{C}, R_{s t}^{0}, \text { not } \\
\text { exceeding }\end{array}$ & $\mathrm{MPa}$ & 13.0 \\
\hline$Y_{3}$ & $\begin{array}{l}\text { Compressive strength } \\
\text { at } 50^{\circ} \mathrm{C}, R_{s t}^{50}, \text { at least }\end{array}$ & $\mathrm{MPa}$ & 1.1 \\
\hline
\end{tabular}

Underlying the mathematical model is a regression equation represented in the following form [15]:

$$
y=b_{0}+b_{1} x_{1}+b_{2} x_{2}+b_{1} 1 x_{1}^{2}+b_{1} 2 x_{1} x_{2}+b_{2} 2 x_{2}^{2},
$$

where $b_{0}$ is the equation's free term; $b_{1}$ are the equation's linear terms coefficients; $b_{i j}$ are the coefficients of the equation's terms paired interactions; $x_{i}, x_{j}$ are the encoded form of input factors.
To determine the $b_{0}, b_{1}, b_{i j}$ coefficients, it is necessary to build and solve 3 equations whose unknowns are the parameters of a given function, therefore, it is necessary to carry out at least 9 experiments based on a full factorial experiment plan (Table 7). The experiments were conducted taking into consideration the requirements set by DSTU B V. 2.7-319:2016 «Asphalt concrete mixes and road and airfield asphalt concrete. Test methods».

Table 7

\begin{tabular}{|c|c|c|c|c|c|c|c|c|}
\hline \multirow{3}{*}{$\begin{array}{c}\text { Experi- } \\
\text { ment } \\
\text { No. }\end{array}$} & \multirow{3}{*}{$\begin{array}{c}\text { Experi- } \\
\text { ment } \\
\text { order }\end{array}$} & \multicolumn{4}{|c|}{ Variation factor value } & \multirow{2}{*}{\multicolumn{3}{|c|}{$\begin{array}{c}\text { Response } \\
\text { function value }\end{array}$}} \\
\hline & & \multicolumn{2}{|c|}{ Encoded } & \multicolumn{2}{|c|}{ Natural } & & & \\
\hline & & $X_{1}, \%$ & $X_{2}, \%$ & $X_{1}, \%$ & $X_{2}, \%$ & $Y_{1}, \%$ & $Y_{2}, \mathrm{MPa}$ & $Y_{3}, \mathrm{MPa}$ \\
\hline 1 & 8 & -1 & -1 & 100 & 0.2 & 5.34 & 11.72 & 1.65 \\
\hline 2 & 9 & -1 & 0 & 100 & 0.25 & 4.82 & 11.26 & 1.49 \\
\hline 3 & 7 & -1 & 1 & 100 & 0.3 & 4.45 & 10.50 & 1.22 \\
\hline 4 & 5 & 0 & -1 & 120 & 0.2 & 4.17 & 10.99 & 1.56 \\
\hline 5 & 3 & 0 & 0 & 120 & 0.25 & 3.86 & 10.54 & 1.28 \\
\hline 6 & 2 & 0 & 1 & 120 & 0.3 & 3.36 & 9.31 & 1.17 \\
\hline 7 & 1 & 1 & -1 & 140 & 0.2 & 3.25 & 11.96 & 1.47 \\
\hline 8 & 4 & 1 & 0 & 140 & 0.25 & 2.69 & 11.66 & 1.29 \\
\hline 9 & 6 & 1 & 1 & 140 & 0.3 & 2.68 & 11.17 & 1.18 \\
\hline
\end{tabular}

Planning matrix, results of experiments

The coefficients for the regression equation and the mathematical models follow:

- for optimization parameter $Y_{1}$ :

$$
\begin{aligned}
& b_{0}=18.8467 ; \quad b_{1}=-0.1149 ; \quad b_{2}=-34.1667 ; \\
& b_{11}=0.0002 ; \quad b_{12}=0.08 ; \quad b_{22}=34 ; \\
& Y_{1}=18.8467-0.1149 x_{1}-34.1667 x_{2}+ \\
& +0.0002 x_{1}^{2}+0.08 x_{1} x_{2}+34 x_{2}^{2} ; \\
& - \text { for optimization parameter } Y_{2}: \\
& b_{0}=49.6594 ; \quad b_{1}=-0.675 ; \quad b_{2}=17.1333 ; \\
& b_{11}=0.0027 ; \quad b_{12}=0.1075 ; \quad b_{22}=84.6667 ; \\
& Y_{2}=49.6594-0.675 x_{1}+17.1333 x_{2}+ \\
& +0.0027 x_{1}^{2}+0.1075 x_{1} x_{2}+84.6667 x_{2}^{2} ;
\end{aligned}
$$

- for optimization parameter $Y_{3}$ :

$b_{0}=5.9389 ; \quad b_{1}=-0.0402 ; \quad b_{2}=-12.2333 ;$

$b_{11}=0.0001 ; \quad b_{12}=0.035 ; \quad b_{22}=8.6667$;

$Y_{3}=5.9389-0.0402 x_{1}-12.2333 x_{2}+$

$+0.0001 x_{1}^{2}+0.035 x_{1} x_{2}+8.6667 x_{2}^{2}$.

Given the significance of the regression equation coefficients, we obtain the following mathematical models of the optimization parameters:

$$
\begin{aligned}
& Y_{1}=18.8467-0.1149 x_{1}- \\
& -34.1667 x_{2}+0.08 x_{1} x_{2}+34 x_{2}^{2} \\
& Y_{2}=49.6594-0.675 x_{1}+ \\
& +17.1333 x_{2}+0.1075 x_{1} x_{2}+84.6667 x_{2}^{2}
\end{aligned}
$$




$$
\begin{aligned}
& Y_{3}=5.9389-0.0402 x_{1}- \\
& -12.2333 x_{2}+0.035 x_{1} x_{2}+8.6667 x_{2}^{2} .
\end{aligned}
$$

In order to assess the suitability of the obtained models, we determined the parameters of the relative error between the calculated and experimental values. For each model, the specified indicator does not exceed $5 \%$, so the models are adequate. The results of the relative errors for the corresponding models are shown in Fig. 1.
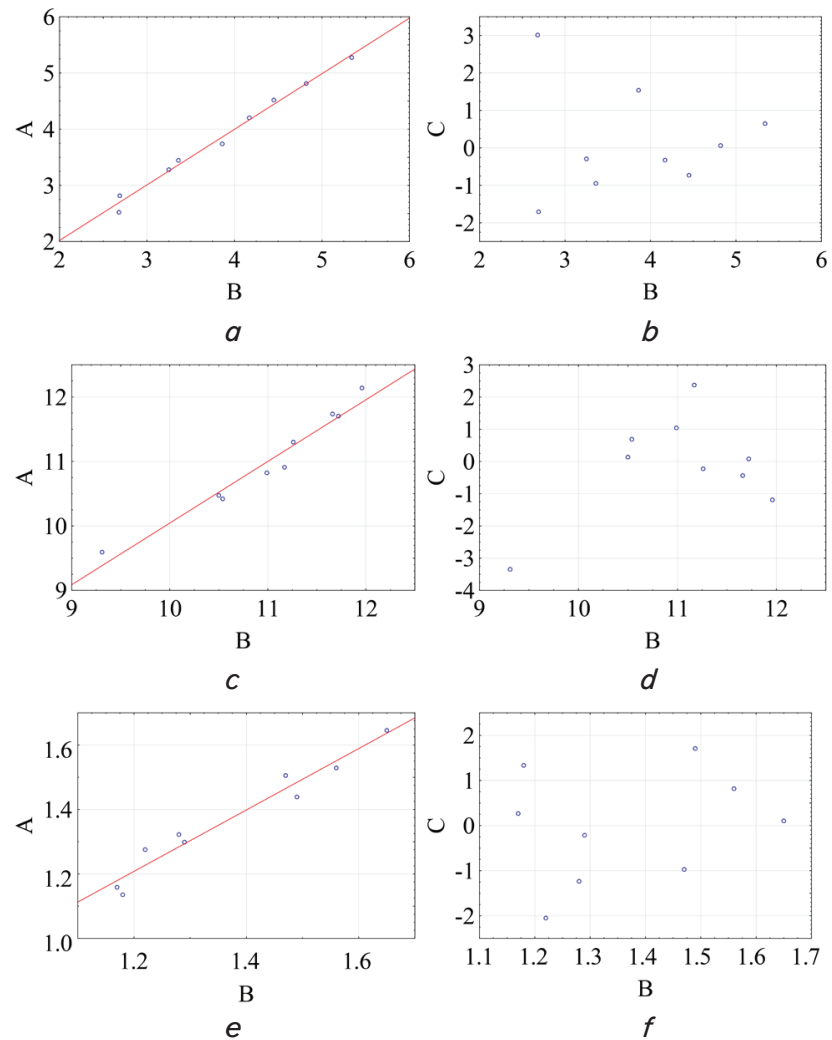

Fig. 1. Chart of the calculated and experimental values of the response function, as well as the relative error estimation: $A$ - Estimated values; $B$ - Experimental values; $C$ - Relative error; $a, b-$ for $Y 1 ; c, d-$ for $Y 2 ; e, f-$ for $Y_{3}$

\section{3. Determining the region of rational technological} parameters

Based on the experimental study, we built the three-dimensional charts (Fig. 2) of change in the output parameters that need to be optimized. Each chart clearly demonstrates regions that are limited by the boundary values; one can easily determine the borders of these regions on the corresponding charts.

Fig. 2 shows the boundary values for the output parameters: $a-Y 13.5 \% ; b-Y 213 \mathrm{MPa} ; c-Y 31.1 \mathrm{MPa}$. Based on the boundary values for the output parameters, it is possible to conclude that $Y 2$ and $Y 3$ fully satisfy all examined regions, and $\mathrm{Y} 1$ - only within $3.5 \%$.

Implementation of the procedure for determining the rational temperature mode of preparing the mixture and the content of a regenerating additive at hot recycling of asphalt concrete coating by the «in place» method is shown in Fig. 3. For this purpose, the desirability values were selected for each response function. When choosing, we took into consideration their boundary values, given in Table 6 .

Fig. 3 shows the charts of change in water saturation, compressive strength at $0{ }^{\circ} \mathrm{C}$ and $50{ }^{\circ} \mathrm{C}$, depending on the change in the output parameters. Adding individual charts make it possible to determine the rational regions of the output parameters.
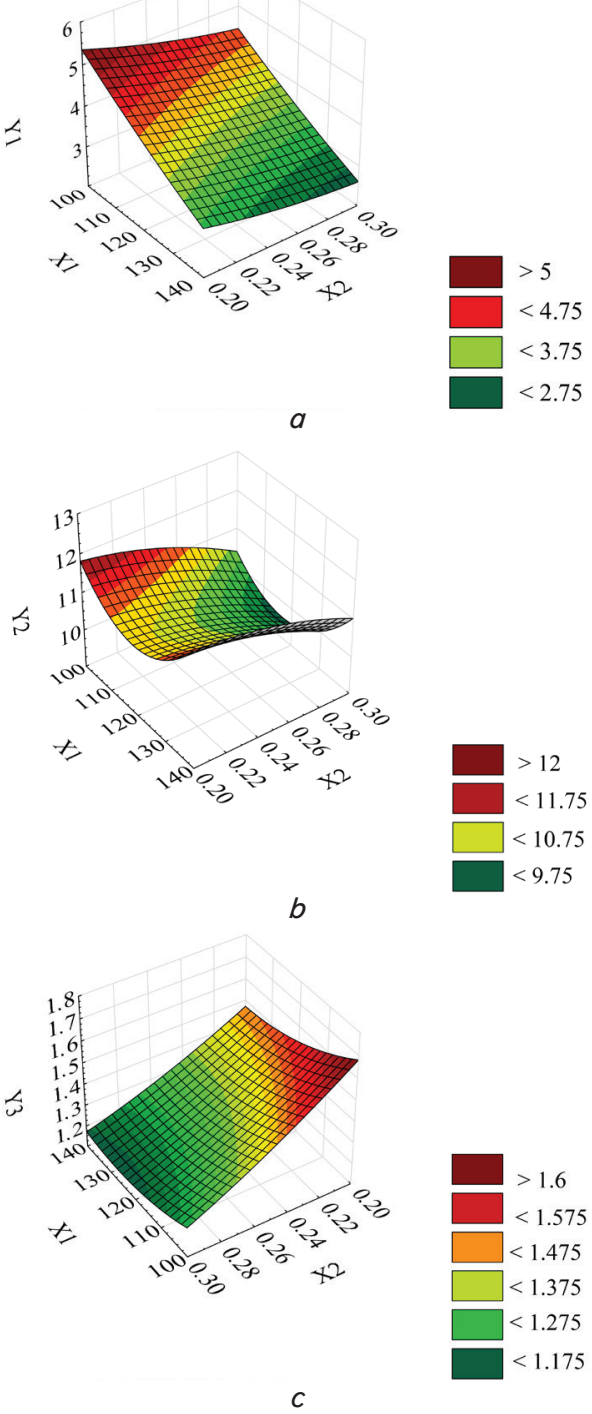

Fig. 2. Three-dimensional graphic

dependences: $a-$ the dependence of $Y 1$ on $X 1$ and $X 2$; $b$ - the dependence of $Y 2$ on $X 5$ and $X 2 ; c-$ the dependence of $Y 3$ on $X 1$ and $X 2$

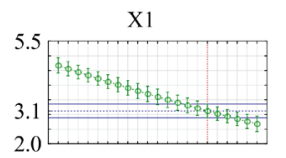

$\mathrm{X} 2$
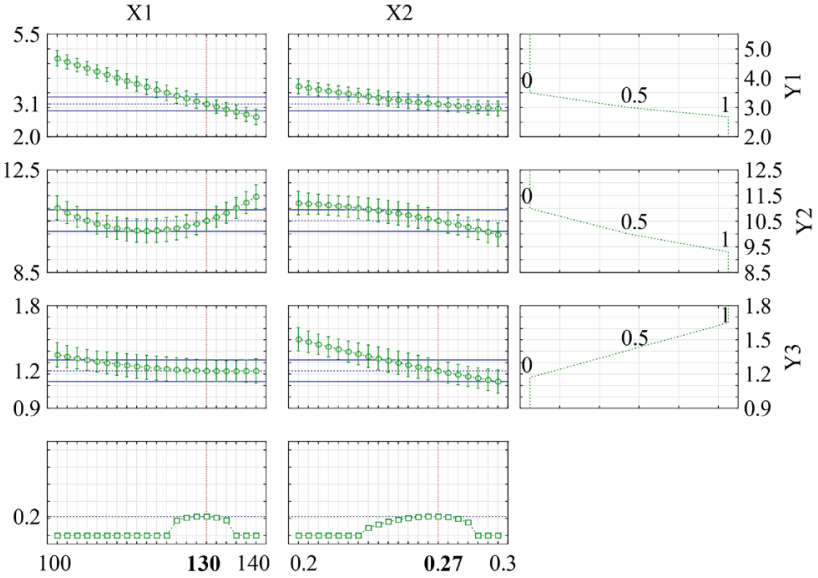

Fig. 3. Charts to determine the rational ratio of the temperature mode of mixture preparation and the content of a regenerating additive 
Given the boundary values of optimization parameters, we determined the rational regions of the examined parameters:

- the temperature of mixture preparation $-(125-135){ }^{\circ} \mathrm{C}$;

- the content of a regenerating additive $-(0.26-0.28) \%$.

\section{Discussion of results of studying the optimization of parameters in the technology of hot recycling of asphalt concrete coating}

Based on the expert estimation, the most significant factors have been determined (the temperature of stirring and the content of an additive) that influence the kinetics of the regenerated asphalt concrete preparation process. This result is substantiated by using the fundamental statistical methods: formulae (1) to (4) and Tables 1-6.

Based on the experimental study of the regenerated asphalt concrete mixture, we have established dependences between the physical and mechanical parameters of regenerated asphalt concrete (water saturation, compressive strength at $0{ }^{\circ} \mathrm{C}$ and at $50{ }^{\circ} \mathrm{C}$ ) and the temperature of preparation and the content of a regenerating additive. Owing to accounting for the simultaneous influence of the two most important factors on the quality of regenerated asphalt concrete, it was possible to establish the boundaries of the regions of permissible values (Fig. 2), as well as the rational ratios of the mixture preparation temperature and the content of a regenerating additive (Fig. 3 ).

The rational ratios of the examined factors (the mixture preparation temperature $-(125-135){ }^{\circ} \mathrm{C}$; the content of a regenerating additive $-(0.26-0.28) \%)$ make it possible to choose the technological modes of hot recycling on the road most effectively. Considering that study [9] established a range of temperature for warming road surface and preparing the regenerated hot asphalt concrete mixtures $(120-180)^{\circ} \mathrm{C}$, reducing this range would make it possible to receive economic effect due to bringing down energy costs.
However, it should be noted that the results of a given study are only valid for the regeneration of fine-grained dense asphalt concrete, type A, non-intermittent granulometry, grade II in accordance with DSTU B V. 2.7-119:2011 when using the additive of the defined type.

At the same time, further scientific investigations should be aimed at adapting the obtained results for their possible application under different conditions. These conditions include different types of regenerated asphalt concrete, different content of the residual bitumen and a regenerating additive, the regeneration with a possibility of adding a new stone material, bitumen, or asphalt concrete mixture.

The obtained results could be used in practice when setting the rational technological parameters for remixer operation.

\section{Conclusions}

1. It has been established that the main factors that influence the physical-mechanical indicators of regenerated asphalt concrete are the technological temperature of stirring and the content of a regenerating additive.

2. Given the threshold values of optimization parameters, it has been determined that compressive strength at $0{ }^{\circ} \mathrm{C}$ and at $50^{\circ} \mathrm{C}$ completely satisfies all the examined regions; as regards water saturation, only in the region of up to $3.5 \%$. Increasing the technological temperature of stirring leads to a decrease in the water saturation indicator.

3. We have determined regions of the rational values for the accepted variational factors that correspond to the temperature of stirring $(125-135){ }^{\circ} \mathrm{C}$ and the content of an additive (0.26-0.28) \% by weight of the regenerated material. At these values of the factors, the indicator of the water saturation of the regenerated asphalt concrete samples is about $3.1 \%$; compressive strength at $0{ }^{\circ} \mathrm{C}$ is about $10.5 \mathrm{MPa}$; compressive strength at $50^{\circ} \mathrm{C}$ is about $1.2 \mathrm{MPa}$.

\section{References}

1. Bruns, T. (2020). High-elevation Colorado road gets the hot in-place treatment. Roads \& Bridges. Available at: https://www. roadsbridges.com/high-elevation-colorado-road-gets-hot-place-treatment?fbclid = IwAR2ErfIwtxx4WEUAkv2dqpmumRS4176vmMUy-yFEuC6PmsTwHQbtIfwDG3Q

2. Basic asphalt Recycling Manual (2001). US Department of Transportation, Federal Highway Administration, Asphalt Recycling and Reclaiming Association, 277. Available at: https://cdrecycling.org/site/assets/files/1081/1-124-barm1.pdf

3. Dude, A. (2014). Manual series No 2. Asphalt Mix Design Methods. Asphalt Institute. Available at: https://www.academia. edu/39782610/Design_Methods_Asphalt_Mix_7th_Edition_MS-2_Asphalt_Mix_Design_Methods_7th_Edition

4. Kandhal, P., Mallick, R. (1997). Pavement Recycling Guidelines for State and Local Governments. Publ. No. FHWA-SA-98-042. US Department of Transportation, Federal Highway Administration; Research, Development, and Technology. Available at: https:// www.fhwa.dot.gov/pavement/recycling/98042/

5. Dony, A., Colin, J., Bruneau, D., Drouadaine, I., Navaro, J. (2013). Reclaimed asphalt concretes with high recycling rates: Changes in reclaimed binder properties according to rejuvenating agent. Construction and Building Materials, 41, 175-181. doi: https:// doi.org/10.1016/j.conbuildmat.2012.11.031

6. Tereshchenko, T. A. (2014). Shliakhy rozvytku tekhnolohiy hariachoho resaiklinhu dorozhnoho asfaltobetonu. Avtoshliakhovyk Ukrainy, 2, 42-48. Available at: http://nbuv.gov.ua/UJRN/au_2014_2_13

7. Cox, B. C., Howard, I. L., Middleton, A. (2016). Case Study of High-Traffic In-Place Recycling on U.S. Highway 49: Multiyear Performance Assessment. Journal of Transportation Engineering, 142 (12), 05016008. doi: https://doi.org/10.1061/(asce)te.1943-5436.0000900

8. Navaro, J., Bruneau, D., Drouadaine, I., Colin, J., Dony, A., Cournet, J. (2012). Observation and evaluation of the degree of blending of reclaimed asphalt concretes using microscopy image analysis. Construction and Building Materials, 37, 135-143. doi: https:// doi.org/10.1016/j.conbuildmat.2012.07.048 
9. Syun'i, G. K., Usmanov, K. H., Faynberg, E. S. (1984). Regenerirovanniy dorozhniy asfal'tobeton. Moscow: Transport, 118.

10. Li, X., Lv, X., Zhou, Y., You, Z., Chen, Y., Cui, Z., Diab, A. (2020). Homogeneity evaluation of hot in-place recycling asphalt mixture using digital image processing technique. Journal of Cleaner Production, 258, 120524. doi: https://doi.org/10.1016/ j.jclepro.2020.120524

11. Anderson, K. V., Russell, M., Uhlmeyer, J. S. et. al. (2016). Long-Term Performance of a Hot In-Place Recycling Project Final Report. Washington State Department of Transportation, 99. Available at: https://www.wsdot.wa.gov/research/reports/ fullreports/738.2.pdf

12. Liu, Y., Wang, H., Tighe, S. L., Zhao, G., You, Z. (2019). Effects of preheating conditions on performance and workability of hot in-place recycled asphalt mixtures. Construction and Building Materials, 226, 288-298. doi: https://doi.org/10.1016/ j.conbuildmat.2019.07.277

13. Slavinska, O., Stozhka, V., Kharchenko, A., Bubela, A., Kvatadze, A. (2019). Development of a model of the weight of motor roads parameters as part of the information and management system of monetary evaluation. Eastern-European Journal of Enterprise Technologies, 1 (3 (97)), 46-59. doi: https://doi.org/10.15587/1729-4061.2019.156519

14. Slavinska, O., Savenko, V., Kharchenko, A., Bubela, A. (2017). Development of a mathematical model of eevaluation of road-andtransport assets as a component of information-and-management system. Eastern-European Journal of Enterprise Technologies, 6 (4 (90)), 45-57. doi: https://doi.org/10.15587/1729-4061.2017.118798

15. Nechaiev, V. P., Beridze, T. M., Kononenko, V. V., Riabushenko, N. V., Bradul, O. M. (2005). Teoriya planuvannia eksperymentu. Kyiv: Kondor, 232. 